\title{
МЕТОДОЛОГІЧНІ ТА ТЕОРЕТИЧНІ ЗАСАДИ ОРГАНІЗАЦЇ̈ ПЕДАГОГІЧНОЇ ОСВІТИ В НОРВЕГІї
}

\author{
(C) Трухан Г.В., 2019 \\ http://orcid.org/0000-0001-7075-5183 \\ http://doi.org/10.34142/2312-2471.2019.62.19
}

У статті визначено методологічні та теоретичні засади організаціі педагогічної освіти в Норвегії. Доведено, щзо в умовах активного реформування вищиӧ педагогічної освіти в України доцільно ретельно вивчати та творчо застосувати на практиці педагогічні доробки зарубіжних фахівців з проблеми здійснення професійної підготовки майбутніх учителів. Мета статті полягає y визначенні методологічних цे теоретичних засад організації вищзӧ педагогічної освіти в Норвегії. На основі опрацюювання широкого кола наукових джерел з'ясовано, щзо педагогічна освіта в Норвегї має високий ступінь доступності та гнучкості, а ї̈ розвиток $\epsilon$ важливою складовою освітньої політики держави. З'ясовано, щзо стан сучасної педагогічної галузі норвезької освіти є результатом багаторічних реформаторських процуесів. У публікації наведено перелік нормативних документів, щуо складають законодавчу базу та структуру вищиӧ педагогічної освіти країни. Проаналізовано та узагальнено погляди сучасних науковців щзодо визначення підходів $і$ принципів реалізациї норвезької системи педагогічної освіти. Доведено, щзо методологічну базу забезпечення професійної підготовки майбутніх вчителів у Норвегї̈ займають такі підходи: діяльнісний підхід (передбачає занурення студентів в активну практичну діяльність); діалоговий підхід (спрямовує зусилля всіх учасників освітнього процесу на розбудову ефективних міжособистісних відносин); особистісний підхід (вимагає орієнтацію освітнього процеесу на особистість студента як мету, суб'єкт, результат $і$ головний критерій ефективності ичього процуесу). У статті також виявлено пріоритетні принципи норвезької педагогічної освіті, серед яких: повага до особистості, включення студента в особистісно значущу діяльність, віра в його позитивний потенціал, принции співробітництва, принции гуманізму тощзо. Установлено, щзо важливими напрямами планування змісту програм педагогічної підготовки студентів $у$ Норвегії є забезпечення оволодіння студентами механізмами самореалізаџї, саморегуляиії, готовністю до адаптації й інтеграції в ивидко змінюваному суспільстві. Наголошено на важливості педагогічної практики, якій у норвезькій системі педагогічної освіти приділяється багато уваги. $У$ подальшому дослідженні передбачається виявити перспективні напрями використання теоретичних та практичних напрацюювань з організації педагогічної освіти в Норвегї в системі вищзої педагогічної освіти в Украӥні.

Ключові слова: вищуа педагогічна освіта, учитель, професійна підготовка, підходи, принциии, Новергія. 


\section{Trukhan H.V. Methodological and Theoretical Principles of Pedagogical Education Organization in Norway.}

The article defines the methodological and theoretical principles of the pedagogical education organization in Norway. It was proved that in the conditions of active reforming higher pedagogical education in Ukraine it is advisable to study carefully and apply creatively in practice the pedagogical achievements of foreign specialists on the problem of professional training of future teachers. The purpose of the article is to determine the methodological and theoretical principles of the organization of higher pedagogical education in Norway. Based on a wide range of scientific sources, it has been found that pedagogical education in Norway has a high degree of accessibility and flexibility, and its development is an important component of the state's educational policy. The state of the modern pedagogical field of Norwegian education has been found to be the result of many years of reform processes. The publication contains a list of normative documents that make up the legal framework and structure of higher pedagogical education in the country. The views of modern scholars on the definition of approaches and principles of the Norwegian system of pedagogical education have been analyzed and generalized. It was proved also that the methodological basis for providing professional training for future teachers in Norway is occupied by the following approaches: activity approach (involves the students' immersion in active practice); dialogic approach (directs the efforts of all participants in the educational process to build effective interpersonal relationships); personal approach (requires the orientation of the educational process on a student's personality as a goal, subject, result and the main criterion for the effectiveness of this process). The article also reveals the priority principles of Norwegian pedagogical education, including: respect for an individual, inclusion of a student in personal meaningful activities, belief in a student's positive potential, the cooperation principle, the humanism principle and more. It has been established that important areas of planning the content of pedagogical training programs for students in Norway are to ensure that students master the mechanisms of self-realization, self-regulation, readiness for adaptation and integration in a rapidly changing society. The importance of pedagogical practice is emphasized, that is of great importance in the Norwegian system of pedagogical education. Further research is expected to identify promising areas of use theoretical and practical developments in the organization of pedagogical education in Norway in the system of higher pedagogical education in Ukraine.

Key words: higher pedagogical education, teacher, professional training, approaches, principles, Norway.

Постановка проблеми. У сучасних умовах активного входження України в європейський освітній простір спостерігається перехід від авторитарної моделі вищої педагогічної освіти до демократичної, що актуалізує цілий ряд проблем, пов'язаних 3 істотною зміною загальної стратегії іiі розвитку. У пошуку оптимальних рішень розв’язання цих проблем доцільним 
кроком $\epsilon$ звернення до перспективних педагогічних доробок зарубіжних фахівців. Зокрема, актуальним для сьогодення $\epsilon$ дослідження стану вищої педагогічної освіти Норвегії.

Вибір цієї країни зумовлений тим, що Норвегія $є$ визнаним лідером у рейтингах розвитку людського потенціалу й якості життя (ООН), перевершуючи успіхи більш розвинених в економічному відношенні країн (США, Канада). Успіхи зазначеної країни значною мірою пояснюється прогресивністю її системи освіти. Беручи активну участь у всіх європейських освітніх проєктах («Інформаційні технології в освіті», «Сократ», «Програма по створенню єдиного освітнього простору» тощо), Норвегія сама використовує міжнародний позитивний досвід в освітній практиці [10, с. 254]. До того ж Норвезьке Королівство представляє вдалий приклад одночасно егалітарної, централізованої й соціально орієнтованої скандинавської моделі системи вищої освіти, що пройшла низьку реформувань, досягнувши якісних результатів.

Аналіз останніх досліджень і публікацій. Аналіз існуючих на сьогодення робіт, присвячених проблематиці підготовки педагогів в Норвегії, засвідчив значну зацікавленість науковців зазначеною темою, водночас вони торкаються лише окремих аспектів проблеми. Так, у дослідженнях I. Броха, В. Вахштайна, Г. Ноканнеса, В. Тропнікової, А. Флестранда висвітлено основні напрямки реформування системи освіти Норвегії та результати цих реформ. У наукових працях Н. Колеснікової, Н. Макарової, Ю. Максимова викладено питання розвитку систем суспільного дошкільного виховання в цій країні.

Наукові розвідки О. Денисової й М. Шаповалової присвячено визначенню тенденцій розвитку норвезької інклюзивної освіти дітей 3 обмеженими можливостями здоров’я. Витоки ефективних моделей педагогічної діяльності в цій країні з'ясовано в доробках О. Оржеховської. Результати дослідницької роботи Є. Богомолової та А. Кириченко пов'язані з розкриттям проблематики підготовки педагогів до всебічного розвитку особистості учнів в Норвегії. У контексті порушеної проблеми особливий інтерес мали дисертація В. Семілетка, присвячена системі підготовки педагогічних кадрів у Норвегіï, а також дисертаційна праця О. Смельянової про підготовку шкільного вчителя в системі педагогічної освіти Норвегії.

Виділення невирішених раніше частин загальної проблеми. Водночас, варто зазначити, що педагогічна система в Норвегії $\epsilon$ не статичним, а динамічним явищем. Тому, не дивлячись на різноманітність напрямів вивчення цієї системи, проблема підготовки педагогів вимагає дослідження.

Формування цілей статті. Мета статті - на основі наукової літератури визначити методологічні й теоретичні засади організації вищої педагогічної освіти в Норвегії.

Виклад основного матеріалу. Як свідчать наукові джерела, норвезька система освіти сьогодні $є$ результатом тривалого складного шляху розвитку, однією 3 цілей якої $є$ охоплення всіх верств населення та включення його в неперервний освітній процес [3, с. 83]. Також установлено, що законодавчу базу, яка регламентує систему освіти в країні, складають такі нормативні 
документи: «Закон про середню школу», «Закон про старшу середню школу», «Закон про професійну підготовку на виробництві», «Закон про навчання дорослих», «Закон про вищі народні школи» тощо [8, с.103]. Тривалість навчання в закладах вищої освіти - від 2 до 8 років (навчання в коледжі 3 отриманням професії i диплома - 1-3 роки; бакалаврат - 3-3,5 роки; магістратура - 2 роки; докторантура - близько 3 -х років; друга вища освіта - у середньому 2 роки) [11, с. 64].

Норвезька система вищої освіти включає: університети (фокусують свою діяльність на теоретичних дисциплінах); університетські коледжі (надають широкий спектр освітніх послуг, в тому числі дають можливість студентам оволодіти спеціальністю вчителя). По закінченню випускники отримують освітньо-кваліфікаційний рівень бакалавра [4, с. 209]. Курс на зближення академічної професійного вищої освіти став одним 3 основних векторів розвитку норвезької системи вищої освіти в другій половині ХХ ст., початку XXI ст., тому між підсистемами коледжів і університетів в Норвегії практично немає статусної нерівності.

Особлива увага в Норвегії приділяється педагогічній освіті, що має високу ступінь доступності й гнучкості. Тому іï розвиток $\epsilon$ важливою складовою освітньої політики держави. Як установлено в дослідженні, діяльність закладів освіти, що здійснюють професійно-педагогічну підготовку вчителів, сьогодні контролює уряд Норвегії. Саме Міністерство освіти, науки і церкви визначає стратегії реформування системи педагогічної освіти, керуючись достовірною інформацією про потреби суспільства й індивідуальні запити особистості [11, с. 64].

Зазначимо, що ті, хто вирішив стати вчителем, може отримати педагогічну освіту в двадцяти п'яти педагогічних коледжах країни (базова педагогічна освіта) й шести університетах (вища педагогічна освіта). Крім того, у цих закладах можуть навчатися ті, хто вже працюють учителями, й ті, хто працював раніше в іншій галузі [7, с. 463-464].

Для кращого розуміння курсу подальшого розвитку й особливостей норвезької освітньої моделі вищої педагогічної освіти вважаємо за доцільне визначити основні методологічні й теоретичні засади іiі організації. У світлі цього варто зазначити, що методологічні основи організації цієї освіти взаємопов'язані з етапами історичного розвитку системи педагогічної освіти країни. Кожна історична епоха вносила свої корективи в розуміння основоположних принципів і підходів до організації процесу навчання, а незалежна норвезька держава прагнула сформувати вільну, творчу особистість.

У зв'язку з цим, в основу педагогічної підготовки норвезьких студентів покладено європейські педагогічні підходи та концепції організації процесу навчання. Як вважає О. Смельянова, така тенденція значною мірою пояснюється відсутністю в Норвегії власної злагодженої системи педагогічної освіти, тому іiі спрямованість на інтеграцію у світовий освітній простір зумовлена підвищеною увагою до європейських теорій, підходів в організації педагогічної підготовки вчителів [5, с. 18-19]. 
У руслі порушеної проблеми дослідження доцільно також визначити провідні методологічні підходи, що складають концептуальне підгрунтя педагогічної освіти в Норвегії, а також основні принципи організації педагогічної підготовки студентів, в яких відбито основні вимоги до організації освітнього процесу. Так, одним із важливих компонентів методологічної основи підготовки майбутніх вчителів в Норвегії є діяльнісний підхід, що забезпечує їх занурення в практичну діяльність, розвиток і закріплення отриманих теоретичних знань через трансформацію отриманої інформації в професійні навички і вміння.

Саме цей підхід сприяє підготовці особистості до самостійної й різнобічної діяльності, вимагаючи переходу студента 3 позиції того, хто навчається, у позицію активного суб'єкта пізнання, праці та спілкування. Під час реалізації вказаного підходу викладачі педагогічних коледжів та університетів Норвегії, керуючись принципом визнання прав людини на пошук свого шляху самовираження, принципом активності студента до пошуку нових знань, принципом включення особистості в значущу діяльність, принципом віри в позитивний потенціал особистості мотивують та активізують студента в опануванні теоретичного і практичного матеріалу [5, с. 44-45].

Важливо, що принцип поваги до особистості, який виражається в прийнятті права людини шукати свій особистий шлях самовираження $\epsilon$ пріоритетним в педагогічній освіті Норвегії. Завдяки творчому пошуку варіантів розвитку, адекватних можливостям і здібностям індивіда, відбувається становлення особистості.

Наступним принципом організації педагогічної підготовки, на думку Н. Макарової, є прояв студентом активності в пошуку нового знання. У світлі цього педагоги норвезьких коледжів і університетів знайомлять майбутніх вчителів 3 технологіями пошуку нового знання. Основне значення надається навичкам критичного, аналітичного підходу до вирішення проблем, умінню обгрунтувати свій вибір [6, с. 23].

Крім того, важливе значення має забезпечення оволодіння здобувачами у вищій школі Норвегії механізмами самореалізації й саморегуляції, уміннями гнучко реагувати на зміни, що відбуваються, готовністю адекватної адаптації й інтеграції в швидко змінюваному суспільстві [9, с.18]. При цьому О. Смельянова зауважує, що саме тому більшість семінарських занять у педагогічних коледжах i норвезьких університетах відводиться для самостійного пошуку студентами нової інформації в процесі виконання групових та індивідуальних проектів, участі в рольових і ділових іграх [5, с. 47].

Ще одним важливим принципом, пов'язаним з указаним вище підходом, $\epsilon$ принцип включення студента в особистісно значущу для нього діяльність. У свою чергу, цей принцип тісно пов'язаний з принципом стимулювання його активності в освітньому процесі, бо ефективність розвитку творчої особистості залежить саме від організації різних видів діяльності, котрі сприяють саморозвитку того, хто навчаться. Застосування викладачами в освітньому 
процесі різноманітних інтерактивних форм і видів діяльності (есе, мозковий штурм, рольові ігри, проєктна діяльність) дають кожному студенту змогу краще усвідомлювати свою особистісну значущість, розкривати свій внутрішній потенціал.

3 погляду В. Громової, ще одним важливим принципом організації педагогічної підготовки вчителів в Норвегії $\epsilon$ віра в позитивний потенціал студента. Студент сприймається педагогами як особистість, що володіє необмеженими творчими можливостями постійного розвитку й самовдосконалення. Для розвитку позитивного потенціалу у процесі педагогічної підготовки студентам пропонується вирішувати «відкриті ситуації», що вимагають пошуку нестандартних шляхів вирішення поставлених перед ними завдань. При цьому в норвезькій системі педагогічної освіти необхідними показниками творчої особистості вважається прагнення студентів до відкриття нового, уміння бачити проблемні аспекти ситуації, прояв самостійності та креативності у вирішенні поставлених завдань [7, с. 464].

Забезпечення самореалізації особистості в процесі активної пізнавальної діяльності сприяє також принцип віри в іï позитивний потенціал. Слід зазначити, що важливим фактором розвитку творчих здібностей студента $\epsilon$ наявність вибору індивідуальної програми навчання. Студенти коледжів i університетів Норвегії, отримуючи на початку року каталог, який містить детальну інформацію щодо пропонованих курсів, самостійно або за допомогою тьютора, обирають 3 них визначену кількість та складають план роботи на семестр, виходячи із власних потреб і мотивів. Згідно з ідеями Джона Дьюї, які покладені в основу педагогічної підготовки вчителів в Норвегії, «не програма, а той, хто навчається, має визначати як якість, так і обсяг свого навчання» $[5, \mathrm{c}$. 48].

Важливе місце серед методологічних підходів, що складають методологічну основу організації підготовки студентів в Норвегії, займає діалоговий підхід, який сприяє самовдосконаленню й саморозвитку особистості студента в умовах взаємодії з іншими людьми. Указаний підхід передбачає активне використання в навчанні студентів бесід, дискусій, диспутів з проблем, які розглядаються під час вивчення дисциплін. А це, у свою чергу, сприяє формуванню у студентів таких якостей, як автономність, самостійність, незалежність, активна життєва позиція тощо [5, с. 46-48].

Слід зазначити, що успішність реалізації діалогового підходу стає можливою при дотриманні умов організації процесу педагогічної підготовки на основі принципу співробітництва викладача та студента. Цей підхід дозволяє розбудовувати ефективні міжособистісні відносини студентів всередині навчальної групи, де важливим завданням педагога є об'єднання суб'єктів навчання, дати їм можливість пізнати кращі один одного [7, с. 465].

Важливу роль в організації педагогічної підготовки вчителів у Норвегії виконує особистісний підхід, який означає орієнтацію на особистість як мету, суб'єкт, результат і головний критерій ефективності педагогічного процесу. Названий підхід вимагає не тільки визнання унікальності особистості, а i 
створення оптимальних умов для саморозвитку та реалізації творчого потенціалу особистості.

Реалізація особистісного підходу в норвезькій педагогічній освіті забезпечується в першу чергу завдяки дотримання принципів гуманізму й цивілізаційного підходу. Як уточнює I. Брох, принцип гуманізації «визначає загальний характер відносин педагога i студентів, майбутніх вчителів у норвезькій системі педагогічної освіти» [3, с. 85]. Головною цінністю є студент зі своїм внутрішнім світом, здібностями, потребами та інтересами. Педагог виступає фасилітатором/ наставником, який супроводжує, стимулює та допомагає студенту в його розвитку та становленні як суб'єкта культури [11, с. 84]. Вищезазначений принцип реалізується під час знайомства студента 3 традиціями, культурною спадщиною, обрядами і життям народів Норвегії, за допомогою виконання студентами творчих робіт 3 проблем культурології та етнографії.

Практичний інтерес викликають засоби і методи організації освітнього процесу, що реалізуються норвезькими педагогами з урахуванням культурних $\mathrm{i}$ регіональних особливостей країни. Одним 3 основних засобів та факторів особистісно-професійного розвитку студентів університетів і коледжів Норвегії виступає зміст педагогічної освіти. Зокрема, у документах Міністерства освіти, науки і церкви Норвегії зміст освіти в межах особистісно-орієнтованої освіти трактується як система знань, умінь, досвіду творчої діяльності, що сприяють професійному та особистісному становленню індивіда, а також засвоєнню ним суспільних норм і цінностей [7, с. 461].

Зміст програм педагогічної підготовки студентів в Норвегії орієнтований на оволодіння учнями теоретичними знаннями і практичними навичками, що дозволяють планувати і організовувати свою професійну педагогічну діяльність в умовах гуманізації освіти, а також уміння проводити дослідницьку діяльність. Як вважає Г. Махотіна, ці пріоритетні напрями планування змісту програм педагогічної підготовки студентів в Норвегії відповідають моделі педагогічної освіти, розробленої Н. Бертоном. Ця модель має назву «Модель кубічного вмісту» та містить такі блоки:

- загальнотеоретичні знання;

- початкові знання і вміння організації педагогічної діяльності;

- формування уявлень про функції й ролі вчителя;

- оволодіння моделями взаємодії з оточуючими людьми;

- оволодіння методами педагогічного дослідження;

- розвиток умінь педагогічного цілепокладання й конструювання;

- психолого-педагогічні знання [6, с. 463].

Важливе місце в норвезькій системі педагогічної освіти займає педагогічна практика, організація якої характеризується цілеспрямованістю, безперервністю, комплексністю. Студенти самі беруть участь у плануванні програм цієї практики та отримують можливість розвивати свій творчий потенціал через рішення педагогічних завдань. Супроводжує кожного студента в період практики педагог куратор. 
Цікавим та корисним, з точки зору В. Богомолової, є підхід в організації норвезької вищої педагогічної освіти, який спрямований на розвиток загальної ерудиції, а також розвиток особистісних якостей майбутнього педагога (емпатії, толерантності) та комунікативних умінь спілкування. Оскільки педагогіка $\epsilon$ синтезом науки і мистецтва, для студентів першого року навчання обов'язковим $\epsilon$ викладання курсу «Драма», що дозволяє «глибше зрозуміти сенс людських відносин, духовні символи культурного розвитку, формують ментальність норвезького суспільства» [4, с.84].

Вивчаючи курс, майбутні вчителі вчаться розуміти та приймати індивідуальні відмінності всіх учасників педагогічного процесу (учнів, їx батьків, колег). Оскільки учні мають різні потреби й мотивацію до навчання, кожний із них вимагає пошуку свого індивідуального підходу до організації його навчання. У світлі цього підкреслюється, що «учителю необхідно вміти здійснювати індивідуалізоване навчання різних груп учнів за умови збереження загальних вимог за рахунок використання спеціальних методик навчання, сприяти більш гнучкому переходу учнів з одного освітнього рівня на інший» $[2$, c. 75]. На наш погляд, саме вміння і навички, отримані в ході цих курсів, формують базові вміння для організації продуктивного спілкування з батьками та підтримки сім'ї учня, ураховуючи предмет, завдання і умови спілкування, характеристики його учасників.

Висновки. Детальний аналіз підходів і принципів системи педагогічної освіти в Норвегії дозволяє не тільки визначити загальний курс освітньої політики, а й більш глибоко зрозуміти витоки ефективної педагогічної діяльності в цій країні.

Отже, можна підсумувати, що Норвегія належить до країн 3 високим рівнем вищої педагогічної освіти, загальні принципи якої визначаються доступністю, неперервністю й універсальністю. Специфіка педагогічної вищої освіти в цій країні полягає в якісному поєднанні трьох важливих складових: теоретичної, практичної та високоінноваційної. Це сприяє формуванню активної професійної позиції майбутніх педагогів, становленню їхньої педагогічної майстерності в інтерактивному середовищі, виробленню навичок рефлексії своєї діяльності.

Якість норвезької педагогічної освіти зумовлена також автономією університетів у визначенні змісту підготовки майбутніх шкільних педагогів і автономністю самого вчителя, що проявляється в наявності в нього права вільного вибору методів і засобів навчання. Варто привернути увагу тому факту, що норвежці, прагнучи відповідати світовим тенденціям, прагненням і нормам взаємодії, зберігають свою ідентичність на основі врахування культурних особливостей і всіх груп населення країни.

Слід також зауважити, що дисципліни, які вивчають культуру, спосіб життя та традиції етнічних меншин країни, включені в освітні програми закладів вищої педагогічної освіти Королівства Норвегії. Про ефективність цієї системи свідчить не тільки наявність у сучасній Норвегії висококваліфікованих фахівців у різних галузях (мистецтва, філософії, інженерії, економіки тощо), 
але й визнання цінності й важливості кожної конкретної особистості та необхідності суспільства бути готовим до того, щоб забезпечити всім можливості для рівного максимального розвитку.

У подальшому дослідженні передбачається виявити перспективні напрями використання теоретичних та практичних напрацювань з організації педагогічної освіти в Норвегії в системі вищої педагогічної освіти в Україні.

\section{Лimepamypa}

1. Концепція Нової української школи: Рішення колегії МОН України від 27.10.2016 №10.: офіц..текст. [Електронний ресурс] Київ, 2016. С. 34 https://mon.gov.ua/storage/app/media/zagalna\%20serednya/nova-ukrainska-shkolacompressed.pdf

2. Богомолова Е.В. Подготовка преподавателей зарубежных стран к развитию личности обучающихся. Вестник РГУ им. И. Канта. Педагогические и психологические науки. 2008. №. 11. С. 70-75

3. Broch I. New trends in humanitarian research and education in Norway . Сб. матер. Междунар. научн. конф. Архангельск. 2002. С.83-85.

4. Граб М. В. Особливості професійної підготовки вчителів Данії та Норвегії. Науковий вісник Мукачівського державного університету. Серія «Педагогіка та психологія». Мукачево. 2019. № 2 (10). С. 208-210.

5. Емельянова O.В. Подготовка школьного учителя в системе педагогического образования Норвегии: дис. ...канд. пед. наук за спец.13.00.01 . Поморск. гос. ун-т им. М. В. Ломоносова. Архангельск : ПГУ. 2014. с. 238

6. Макарова Н.В. Система общественного дошкольного воспитания Норвегии: автореф. дис. ...канд. пед. наук за спец. 13.00.01. Мурманск. гос. педагог. универ. Мурманск. 2000. с. 25

7. Махотина Г.Е., В.В. Громова Истоки эффективных моделей педагогической деятельности: опыт Норвегии. Здоровье - основа человеческого потенциала: проблемь и пути их решения : труды IX всерос. научно- практ. конф. с международ. уч. 20 - 22 ноября 2014 г. СПб: СПбГПУ. 2014. - Том 9, часть 1. С. 460-466.

8. Оржеховська О.С. Механізми забезпечення якості шкільної освіти в Норвегії. [Електронний ресурс] Порівняльно-педагогічні студіi.. 2013.№4(18). C. 102-108. Режим доступу: http://nbuv.gov.ua/UJRN/Ppstud_2013_4_17

9. Тевлина В.В. Научно-образовательная политика в Норвегии: национальные и общемировые тенденции развития . Вестник САФУ. Серия: гуманитарные и социальные науки. Архангельск. 2012. №2. С.33-43

10. Тропникова В. В. Международный опыт реформирования систем высшего образования на примере Скандинавских стран. «Концепт», научнометодический электронный журнал, раздел 13.00.00. Педагогические науки. 2017. Режим доступу: №12https://e-koncept.ru/2017/December.htm

11. Флёстранд А.Л. Система педагогического образования Норвегии в контексте современных реформ. Непрерывное педагогическое образование в 
контексте инновационных проектов общуественного развития. Сборник материалов VI Международ. научно-практ. конф. М.2017. С.62-73.

\section{References}

1. Kontseptsiya Novoï ukraïnskoï shkoli: Rishennya kolegiï MON Ukraïni vid 27.10.2016 №10.: ofits..tekst. (2016) [Yelektronniy resurs] Kiï, S. 34. https://mon.gov.ua/storage/app/media/zagalna\%20serednya/nova-ukrainska-shkolacompressed.pdf (in Ukrainian).

2. Bogomolova Ye.V. (2008). Podgotovka prepodavateley zarubezhnykh stran k razvitiyu lichnosti obuchayushchikhsya. Vesnik RGU im. I. Kanta. Pedagogicheskie i psikhologicheskie nauki. №. 11. S. 70-75. (in Russian).

3. Broch I. (2002). New trends in humanitarian research and education in Norway . Sb. mater. Mezhdunar. nauchn. konf. Arkhangelsk. S.83-85. (in Russian).

4. Grab M. V. (2019). Osoblivosti profesiynoï pidgotovki vchiteliv Daniï ta Norvegiï. Naukoviy visnik Mukachivskogo derzhavnogo universitetu. Seriya «Pedagogika ta psikhologiya». Mukachevo. № 2 (10). S. 208-210. (in Ukrainian).

5. Yemelyanova O.V. (2014). Podgotovka shkolnogo uchitelya v sisteme pedagogicheskogo obrazovaniya Norvegii: dis. ...kand. ped. nauk za spets.13.00.01 . Pomorsk. gos. un-t im. M. V. Lomonosova. Arkhangelsk : PGU. s. 238 (in Russian).

6. Makarova N.V. (2000). Sistema obshchestvennogo doshkolnogo vospitaniya Norvegii: avtoref. dis. ...kand. ped. nauk za spets. 13.00.01. Murmansk. gos. pedagog. univer. Murmansk. s. 25. (in Russian).

7. Makhotina G.Ye., V.V. Gromova (2014). Istoki effektivnykh modeley pedagogicheskoy deyatelnosti: opyt Norvegii. Zdorove - osnova chelovecheskogo potentsiala: problemy i puti ikh resheniya : trudy IX vseros. nauchno- prakt. konf. s mezhdunarod. uch. 20 - 22 noyabrya 2014 g. SPb: SPbGPU. Tom 9, chast 1. S. 460-466. (in Russian).

8. Orzhekhovska O.S. (2013). Mekhanizmi zabezpechennya yakosti shkilnoï osviti v Norvegiii. [Yelektronniy resurs] Porivnyalno-pedagogichni studiï. №4(18). S. 102-108. Rezhim dostupu: http://nbuv.gov.ua/UJRN/Ppstud_2013_4_17 (in Ukranian).

9. Tevlina V.V. (2012). Nauchno-obrazovatelnaya politika v Norvegii: natsionalnye i obshchemirovye tendentsii razvitiya . Vestnik SAFU. Seriya: gumanitarnye i sotsialnye nauki. Arkhangelsk. №2. S.33-43. (in Russian).

10. Tropnikova V. V. (2017). Mezhdunarodnyy opyt reformirovaniya sistem vysshego obrazovaniya na primere Skandinavskikh stran. «Kontsept», nauchnometodicheskiy elektronnyy zhurnal, razdel 13.00.00. Pedagogicheskie nauki. Rezhim dostupu: №12https://e-koncept.ru/2017/December.htm (in Russian).

11. Flestrand A.L. (2017). Sistema pedagogicheskogo obrazovaniya Norvegii v kontekste sovremennykh reform. Nepreryvnoe pedagogicheskoe obrazovanie $\mathrm{v}$ kontekste innovatsionnykh proektov obshchestvennogo razvitiya. Sbornik materialov VI Mezhdunarod. nauchno-prakt. konf. M. S.62-73. (in Russian). 